\title{
TABLE DES MATIERES / TABLE OF CONTENTS
}

$\begin{array}{ll}\text { Préface } & 7\end{array}$

$\begin{array}{ll}\text { Preface } & 11\end{array}$

Liste des périodiques (par pays)/List of periodicals (by country) 15

Index des sujets/Subject index $\quad 201$

English key-words for the subject index 213

Index des institutions/Index of institutions $\quad 215$

$\begin{array}{ll}\text { Index des titres/Index of titles } & 227\end{array}$ 
